\title{
Combined in-vitro and on-farm evaluation of commercial disinfectants used against Brachyspira hyodysenteriae
}

Manuel Gómez-García* (D, Héctor Argüello, Lucía Pérez-Pérez, Clara Vega, Héctor Puente, Óscar Mencía-Ares, Pedro Rubio and Ana Carvajal

\begin{abstract}
Background: Swine dysentery (SD) is a severe infectious disease with a relevant impact on pig production usually caused by Brachyspira hyodysenteriae, although B. hampsonii causes an identical clinical picture. SD control relies on antimicrobials, good management practices and strict biosecurity with cleaning and disinfection as crucial tools to avoid the pathogen transmission. This study evaluates the in-vitro efficacy of an array of commercial disinfectants against a collection of $B$. hyodysenteriae isolates using broth tests. The efficacy of cleaning and disinfection protocols was also evaluated on two farms with endemic SD using surface swabs collected in emptied pens before and after cleaning and disinfection procedures, using both real-time PCR and bacterial microbiological culture.

Results: Most of the commercial disinfectants evaluated were effective against all B. hyodysenteriae isolates tested, with a reduction of more than $5.00 \log _{10} \mathrm{CFU} / \mathrm{mL}$ (bactericidal efficacy of 99.999\%). However, some isolates exhibited reduced susceptibility to Virkon-S and Limoseptic disinfectants. The evaluation of cleaning and disinfection protocols on farms with SD outbreaks showed that approximately half the pens tested $(n=25)$ were positive by real-time PCR after pigs removal (mean B. hyodysenteriae counts $5.72 \pm 1.04 \log _{10} \mathrm{CFU} / \mathrm{mL}$ ) while almost $20 \%$ of the pens remained positive after cleaning $(n=7)$ and disinfection $(n=5)$ procedures although with significantly lower, mean estimates ( $4.31 \pm 0.43 \log _{10} \mathrm{CFU} / \mathrm{mL}$ and $4.01 \pm 0.55 \log _{10} \mathrm{CFU} / \mathrm{mL}$, respectively).
\end{abstract}

Conclusions: These results show the efficacy of disinfectants against $B$. hyodysenteriae but also stress the need to implement adequately the cleaning and disinfection protocols on pig farms and review and revise their efficiency periodically.

Keywords: Swine dysentery, Disinfection, Cleaning, Internal biosecurity

\section{Background}

Swine dysentery (SD) is a severe mucohaemorhagic enteric disease, which causes important losses in the pig industry due to mortality and sub-optimal performance $[1,2]$. The disease is more frequently observed in the growing and finishing stages [3]. The classical etiological agent is Brachyspira hyodysenteriae, a Gram-negative,

\footnotetext{
*Correspondence: mgomg@unileon.es
}

Department of Animal Health, Faculty of Veterinary Medicine, Universidad de León, León, Spain motile, helically coiled, beta-haemolytic and anaerobic bacteria [4]. Brachyspira hyodysenteriae colonizes the lumen and crypts of the porcine caecum and colon causing mucohemorrhagic diarrhoea [1]. Brachyspira hampsonii infection is mainly confined to North America and can cause the same clinical signs $[5,6]$.The transmission by the faecal-oral route occurs by direct contact through the introduction of infected animals into uninfected herds [7] and by indirect contact with contaminated surfaces, where the pathogen is capable of surviving under original author(s) and the source, provide a link to the Creative Commons licence, and indicate if changes were made. The images or other third party material in this article are included in the article's Creative Commons licence, unless indicated otherwise in a credit line to the material. If material is not included in the article's Creative Commons licence and your intended use is not permitted by statutory regulation or exceeds the permitted use, you will need to obtain permission directly from the copyright holder. To view a copy of this licence, visit http://creativecommons.org/licenses/by/4.0/. The Creative Commons Public Domain Dedication waiver (http://creativeco mmons.org/publicdomain/zero/1.0/) applies to the data made available in this article, unless otherwise stated in a credit line to the data. 
favourable conditions such as organic matter, humidity and darkness [3].

Limitations in disease treatment, linked to the emergence of strains with reduced susceptibility to antibiotics or the lack of commercial vaccines, highlight the relevance of other strategies in SD prevention and control [8-10]. High standards in biosecurity are crucial in prevention and amelioration of diseases in pig production $[11,12]$ and management strategies such as all-in /all-out (AI/AO) attempt to be effective firewalls to prevent the transmission of diseases such as SD. Undoubtedly the effectiveness of AI/AO depends on the efficacy of cleaning and disinfection protocols put in place $[2,3,11]$.

Disinfectant choice depends on factors such as microorganism spectrum, surfaces to be treated, applicable temperature range, toxicity or economic constraints [13]. Despite the theoretical efficacy of disinfectants, their misuse favours the emergence and spread of disinfectant tolerance [14] by the selection of resistant clones/strains and the horizontal spread of disinfectant resistance genes [15]. Field studies also reveal the need to implement efficient protocols, which remove the pathogens from the environment successfully [16]. Despite the environmental component in SD epidemiology, there are no studies which particularly combine the assessment of the in-vitro susceptibility of $B$. hyodysenteriae to disinfectants and the efficacy of these agents under the usual cleaning and disinfection protocols implemented in field conditions [2, $17,18]$. With this aim in mind, this study evaluates the in-vitro efficacy of an array of different commercial disinfectants against a collection of ten field isolates of B. hyodysenteriae and the efficacy of hygiene protocols, under field conditions, on farms with SD.

\section{Results}

In-vitro efficacy of disinfectants against $B$. hyodysenteriae

The results of disinfectants activity against $B$. hyodysenteriae are shown in Table 1. Mean B. hyodysenteriae counts in control tests (without disinfectant) was $7.6 \pm 0.2 \log _{10}$ colony forming units $(\mathrm{CFU}) / \mathrm{mL}$ and we observed that disinfectants activity was not inhibited by the interfering substance. All disinfectants, except for Virkon-S and Limoseptic, were capable of inhibiting the B. hyodysenteriae viability completely (reduction of more than 5.00 $\log _{10}$ CFU/mL or $99.999 \%$ efficacy) with no differences among the isolates tested. However, reduced efficacy was observed with VIRKON-S against the isolate IT-40 (average reduction of $\left.2.9 \pm 0.3 \log _{10} \mathrm{CFU} / \mathrm{mL}\right)$, IT-67 (2.2 \pm 0.8 $\left.\log _{10} \mathrm{CFU} / \mathrm{mL}\right)$ and IT-85 $\left(3.1 \pm 0.9 \log _{10} \mathrm{CFU} / \mathrm{mL}\right)$ and with Limoseptic against IT-45 $\left(3.9 \pm 0.6 \log _{10} \mathrm{CFU} / \mathrm{mL}\right)$.

\section{On-farm efficacy of cleaning and disinfection protocols}

As shown in Table 2, detection of B. hyodysenteriae by real-time PCR revealed that $44.6 \%$ of the pens tested $(\mathrm{n}=56)$ were positive to $B$. hyodysenteriae after being emptied of pigs and before they were cleaned (BC). In contrast, only $12.5 \%$ and $8.9 \%$ of the pens tested were positive after cleaning $(\mathrm{AC})$ and after disinfection procedures (AD), respectively. Similar percentages were obtained in the analysis of results for each farm, despite the number of pens tested on farm $B(n=48)$ was considerably higher than on farm $A(n=8)$.

When only B. hyodysenteriae-positive pens $B C(n=25)$ were included in the analysis, the percentage of pens which remained positive AC and AD increased to $28.0 \%$ and $20.0 \%$, respectively. The proportion of positive pens on farm $\mathrm{A}$ both $\mathrm{AC}$ and $\mathrm{AD}$ was lower than on farm $\mathrm{B}$

Table 1 Surviving population of each B. hyodysenteriae isolate after exposure to the disinfectant tested

\begin{tabular}{|c|c|c|c|c|c|c|c|c|c|c|c|}
\hline \multirow{3}{*}{ Disinfectant } & \multicolumn{11}{|c|}{ Mean counts $\left(\log _{10} \mathrm{CFU} / \mathrm{mL}\right)$ and standard deviation $( \pm)$} \\
\hline & \multicolumn{10}{|l|}{ Isolate } & \multirow{2}{*}{$\begin{array}{l}\text { QC strain } \\
\text { B204 }\end{array}$} \\
\hline & IT-1 & IT-18 & IT-39 & IT-40 & IT-45 & IT-48 & IT-67 & IT-68 & IT-83 & IT-85 & \\
\hline $\mathrm{ET}-70 \%{ }^{\mathrm{a}}$ & $0.0 \pm 0.0$ & $0.0 \pm 0.0$ & $0.0 \pm 0.0$ & $0.0 \pm 0.0$ & $0.0 \pm 0.0$ & $0.0 \pm 0.0$ & $0.0 \pm 0.0$ & $0.0 \pm 0.0$ & $0.0 \pm 0.0$ & $0.0 \pm 0.0$ & $0.0 \pm 0.0$ \\
\hline Virkon-S & $0.0 \pm 0.0$ & $0.0 \pm 0.0$ & $0.0 \pm 0.0$ & $4.7 \pm 0.3$ & $0.0 \pm 0.0$ & $0.0 \pm 0.0$ & $5.0 \pm 0.4$ & $0.0 \pm 0.0$ & $0.0 \pm 0.0$ & $4.8 \pm 0.6$ & $0.0 \pm 0.0$ \\
\hline CR-36 & $0.0 \pm 0.0$ & $0.0 \pm 0.0$ & $0.0 \pm 0.0$ & $0.0 \pm 0.0$ & $0.0 \pm 0.0$ & $0.0 \pm 0.0$ & $0.0 \pm 0.0$ & $0.0 \pm 0.0$ & $0.0 \pm 0.0$ & $0.0 \pm 0.0$ & $0.0 \pm 0.0$ \\
\hline Yodermin & $0.0 \pm 0.0$ & $0.0 \pm 0.0$ & $0.0 \pm 0.0$ & $0.0 \pm 0.0$ & $0.0 \pm 0.0$ & $0.0 \pm 0.0$ & $0.0 \pm 0.0$ & $0.0 \pm 0.0$ & $0.0 \pm 0.0$ & $0.0 \pm 0.0$ & $0.0 \pm 0.0$ \\
\hline Poliformo & $0.0 \pm 0.0$ & $0.0 \pm 0.0$ & $0.0 \pm 0.0$ & $0.0 \pm 0.0$ & $0.0 \pm 0.0$ & $0.0 \pm 0.0$ & $0.0 \pm 0.0$ & $0.0 \pm 0.0$ & $0.0 \pm 0.0$ & $0.0 \pm 0.0$ & $0.0 \pm 0.0$ \\
\hline Limoseptic & $0.0 \pm 0.0$ & $0.0 \pm 0.0$ & $0.0 \pm 0.0$ & $0.0 \pm 0.0$ & $3.5 \pm 0.5$ & $0.0 \pm 0.0$ & $0.0 \pm 0.0$ & $0.0 \pm 0.0$ & $0.0 \pm 0.0$ & $0.0 \pm 0.0$ & $0.0 \pm 0.0$ \\
\hline MS Megades Oxy & $0.0 \pm 0.0$ & $0.0 \pm 0.0$ & $0.0 \pm 0.0$ & $0.0 \pm 0.0$ & $0.0 \pm 0.0$ & $0.0 \pm 0.0$ & $0.0 \pm 0.0$ & $0.0 \pm 0.0$ & $0.0 \pm 0.0$ & $0.0 \pm 0.0$ & $0.0 \pm 0.0$ \\
\hline MS Megades Novo & $0.0 \pm 0.0$ & $0.0 \pm 0.0$ & $0.0 \pm 0.0$ & $0.0 \pm 0.0$ & $0.0 \pm 0.0$ & $0.0 \pm 0.0$ & $0.0 \pm 0.0$ & $0.0 \pm 0.0$ & $0.0 \pm 0.0$ & $0.0 \pm 0.0$ & $0.0 \pm 0.0$ \\
\hline $\begin{array}{l}\text { Control } \\
\text { (without disinfectant) }\end{array}$ & $7.8 \pm 0.3$ & $7.7 \pm 0.6$ & $7.4 \pm 0.3$ & $7.5 \pm 0.0$ & $7.5 \pm 0.1$ & $7.5 \pm 0.5$ & $7.5 \pm 0.6$ & $7.4 \pm 1.0$ & $7.6 \pm 1.0$ & $8.0 \pm 0.4$ & $8.1 \pm 0.1$ \\
\hline
\end{tabular}

a Positive control

b Quality control strain 
Table 2 Results of B. hyodysenteriae detection by real-time PCR in the pens sampled

\begin{tabular}{|c|c|c|c|c|c|c|c|c|c|}
\hline & \multicolumn{3}{|c|}{$\begin{array}{l}\text { Before cleaning (BC) } \\
\text { Sampled pens }\end{array}$} & \multicolumn{3}{|c|}{$\begin{array}{l}\text { After cleaning and before disinfection } \\
\text { (AC) } \\
\text { Sampled pens }\end{array}$} & \multicolumn{3}{|c|}{$\begin{array}{l}\text { After disinfection (AD) } \\
\text { Sampled pens }\end{array}$} \\
\hline & Total & Positive & $\%$ & Total & Positive & $\%$ & Total & Positive & $\%$ \\
\hline Combined results & 56 & 25 & 44.6 & 25 & 7 & 28.0 & 25 & 5 & 20.0 \\
\hline Farm A \# & 8 & 6 & 75.0 & 6 & 1 & 16.7 & 6 & 1 & 16.7 \\
\hline Farm B \# & 48 & 19 & 39.6 & 19 & 6 & 31.6 & 19 & 4 & 21.1 \\
\hline
\end{tabular}

\# A two-step protocol including power washing and disinfection with Hypred Force 7 was carried out on Farm A while Farm B cleaning and disinfection protocol included pre-soaking with cold water and detergent, power washing with cold water and final disinfection with MS Megades Oxy

(Table 2), although results did not reach statistical significance $(p>0.05)$.

By using real-time PCR, we also aimed at establishing the $B$. hyodysenteriae counts $\left(\log _{10} \mathrm{CFU} / \mathrm{mL}\right)$ in positive samples (Fig. 1). Estimated mean counts of the pathogen in positive swabs from emptied pens were $5.7 \pm 1.0$ $\log _{10}$ CFU/mL. Mean counts obtained AC ( $4.3 \pm 0.4 \log _{10}$ $\mathrm{CFU} / \mathrm{mL})$ and $\mathrm{AD}\left(4.0 \pm 0.6 \log _{10} \mathrm{CFU} / \mathrm{mL}\right)$ were significantly lower $(p<0.05)$ than $B$. hyodysenteriae values $\mathrm{BC}$ (Fig. 1A). However, we did not observe any significant variation of $\log _{10} \mathrm{CFU} / \mathrm{mL}$ between cleaning and disinfection protocols $(p>0.05)$.

On farm A (Fig. 1B), the only B. hyodysenteriae-positive pen $A C$ showed a lower value of $B$. hyodysenteriae counts $\left(4.5 \pm 0.2 \log _{10} \mathrm{CFU} / \mathrm{mL}\right)$ than the values obtained $\mathrm{BC}$ $\left(6.1 \pm 0.9 \log _{10} \mathrm{CFU} / \mathrm{mL}\right)$ and the bacterial load clearly decreased after disinfection with Hyper Force 7 (3.3 \pm 0.1 $\log _{10} \mathrm{CFU} / \mathrm{mL}$ ). Farm B (Fig. 1C), using MS Megades Oxy, showed similar B. hyodysenteriae estimations. In detail, the means of $\log _{10} \mathrm{CFU} / \mathrm{mL}$ estimated $\mathrm{BC}, \mathrm{AC}$ and AD were $5.6 \pm 1.1,4.3 \pm 0.5$ and $4.2 \pm 0.4$, respectively.

Brachyspira hyodysenteriae could only be isolated from a single environmental sample, which was obtained in the first sampling (BC) on farm B. The quantification of $B$. hyodysenteriae by real-time PCR revealed that the bacterial load in this sample was the highest estimated in our study $\left(7.47 \pm 0.01 \log _{10} \mathrm{CFU} / \mathrm{mL}\right)$. The bacteria did not grow in any other environmental sample, neither positive nor negatives, in the real-time PCR analyses.

\section{Discussion}

Preventive medicine is essential to combat livestock infectious diseases in the post-antibiotic era and biosecurity has gained relevance in difficult-to-control diseases such as SD [19]. Within biosecurity schemes, implementation of effective cleaning and disinfection protocols are mandatory as part of those strategies, which aim at breaking the disease transmission among batches [11]. This fact is supported by observational studies such as the one carried out by Neirynck et al. [2], who only found successful eradication programmes for B. hyodysenteriae on the four farms, which implemented properly cleaning and disinfection procedures, among other biosecurity measures. This efficacy relies on the selection of the most appropriate compounds [14, 15] and their application through effective protocols. In this way, there exist only a few research studies focusing on the susceptibility of B. hyodysenteriae to disinfectants and the efficacy of current cleaning and disinfection protocols on farms with endemic SD.

The results of our study under laboratory conditions confirmed the antibacterial activity of most commercial disinfectants tested against field isolates of B. hyodysenteriae. Earlier studies evaluating the in-vitro activity of disinfectants from different chemical groups against a type strain and a field B. hyodysenteriae isolate [20] or a collection of seven B. pilosicoli [21] converged in the conclusion that disinfectants were effective against Brachyspira spp., even at concentrations lower than that recommended by manufacturers. Our results show that following the European Norm (EN) 1656:2009, most disinfectants can be considered as effective products under the assay conditions, as they reduced $99.999 \%$ of bacteria in suspension after $30 \mathrm{~min}$ of contact. However, the fact that a few numbers of isolates experienced lower sensitivity against Virkon-S, a peroxygen disinfectant and Limoseptic, an ammonium derivate shows that slight strain-dependent variations can occur. It is worth mentioning that two of the four isolates exhibiting higher tolerance to Virkon-S and Limoseptic disinfectants also showed high antibiotic MIC values. The increase and the potential spread of isolates with reduced susceptibility to antibiotics and disinfectants limits two of the most efficient strategies in SD control and highlights the relevance of early detection of these problematic strains.

Sterile faeces are usually included in the in-vitro evaluation of disinfectants. Despite the fact that it has been shown than faeces can increase the MIC of a disinfectant needed to inhibit the growth of Brachyspira spp. $[20,21]$, our results show, as in other studies [22], that 


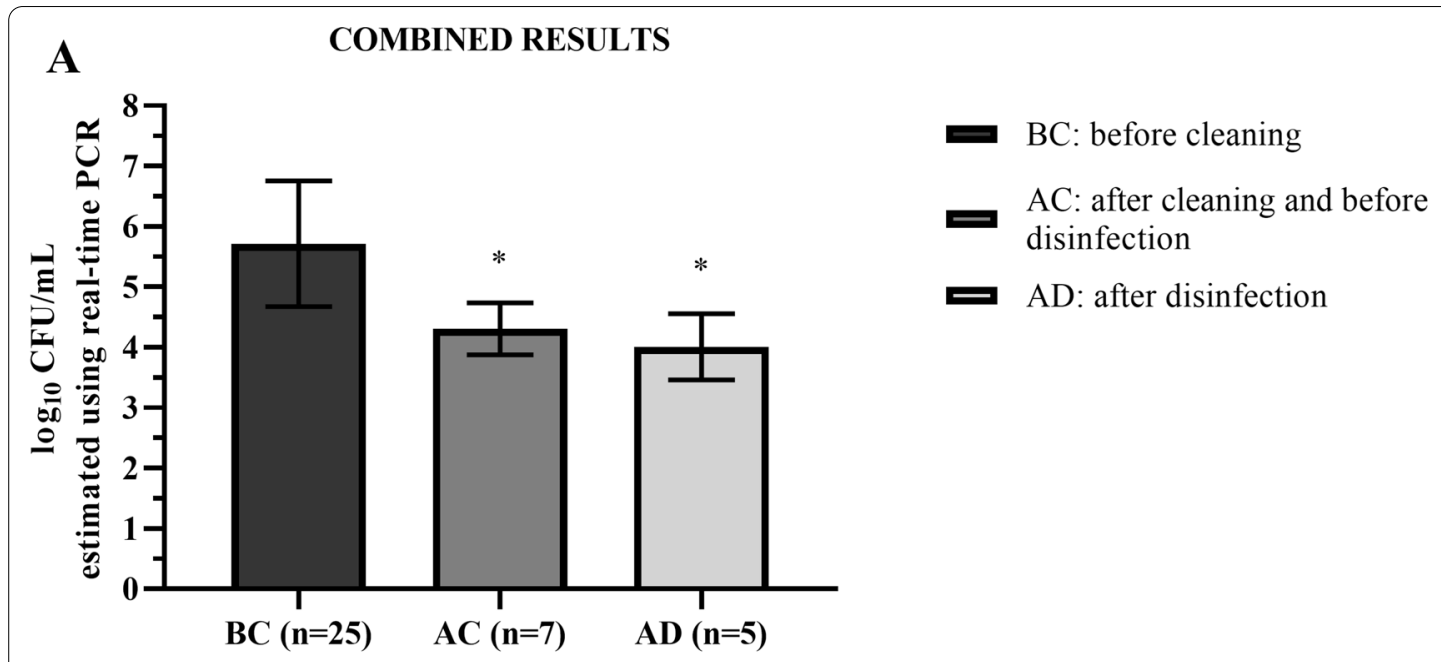

B

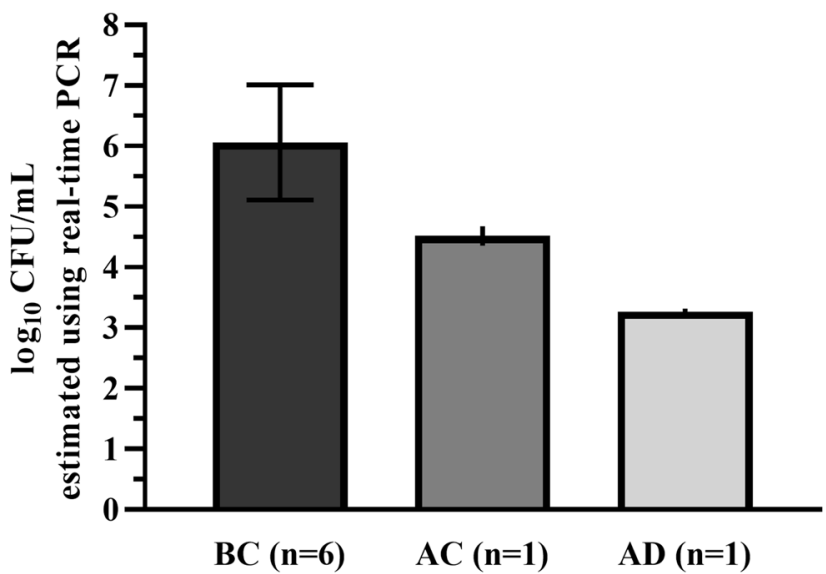

C

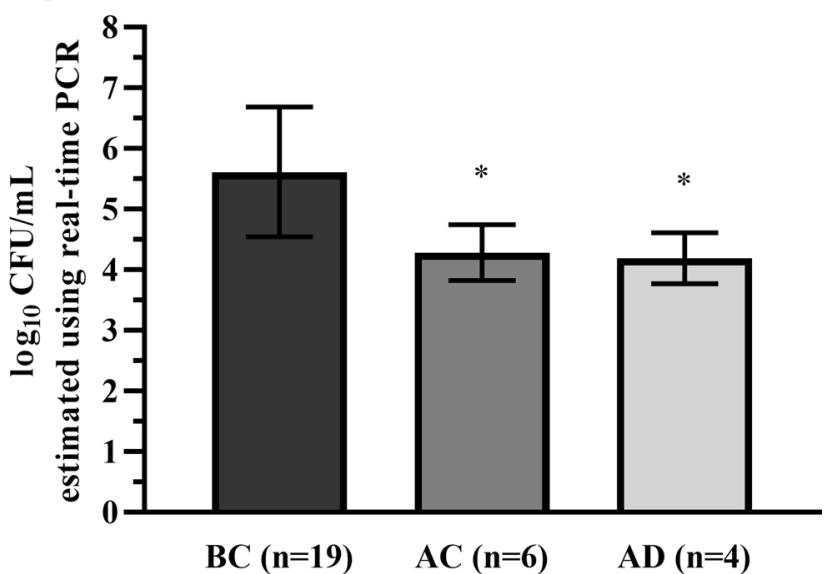

Fig. 1 Mean B. hyodysenteriae counts estimated using real-time PCR in the pens sampled. Mean values \pm standard deviations of $\log _{10} \mathrm{CFU} / \mathrm{mL}$ estimated using real-time PCR in all B. hyodysenteriae-positive pens before cleaning (BC) included in this study (A) as well as on farm $A(B)$ and farm B (C). A two-step protocol including power washing and disinfection with Hypred Force 7 was carried out on Farm A while Farm B cleaning and disinfection protocol included pre-soaking with cold water and detergent, power washing with cold water and final disinfection with MS Megades Oxy. * Denotes statistically significant differences when compared with the B. hyodysenteriae counts before cleaning protocol $(p<0.05)$. Statistical analysis could not be made for Farm A because only one B. hyodysenteriae-positive pen was identified after cleaning and before disinfection (AC) and after disinfection (AD)

the presence of faeces did not affect the in-vitro activity of the compounds at the recommended concentrations. However, we must point out that under field conditions, large amounts of faeces or organic matter can inhibit disinfectant activity [23].

We further researched the efficacy of disinfectants in practice by monitoring routine cleaning and disinfection protocols on two farms with endemic SD. Environmental detection of B. hyodysenteriae in pens from grower and finisher pig batches with clinical outbreaks of SD showed the presence of relevant concentrations of the pathogen in at least half of the pens tested using real-time PCR. Despite the fact that this molecular diagnostic technique does not differentiate viable from non-viable $B$. hyodysenteriae, the DNA mean values reached $\left(5.72 \pm 1.04 \log _{10} \mathrm{CFU} / \mathrm{mL}\right)$ are not far from the experimental dose in SD challenges [24] and provide an idea of the load of pathogen in emptied pens after animals have been moved. However, the parallel culture of fresh samples did not support our PCR results. Brachyspira hyodysenteriae is a fastidious anaerobe and factors such as antimicrobial treatments, time lapse between shedding and sample collection and/or dilution of pathogen concentration 
by dejections may hamper its further laboratory isolation, an experience shared with a previous environmental study of $B$. hyodysenteriae viability [18]. The fact that subsequent batches of pigs experienced SD on both farms points out the viability of the B. hyodysenteriae detected in the pens.

Surface sampling of pens AC and AD highlighted the presence of the pathogen in almost a third of the positive pens, with no improvement of the disinfection step compared to power washing (farm A) or washing with detergent (farm B), a result which contrasts with our in-vitro results and shows the failure of the protocols put in place, particularly on farm B, where the visual inspection of pens evidenced dirty areas after finishing the cleaning protocol (data not shown). Despite that the cleaning and disinfection protocols reduced $80 \%$ of initial $B$. hyodysenteriae-positive pens, viable $B$. hyodysenteriae remaining on pen surfaces, feeders, corridors or equipment are potential source of infection for the forthcoming batches of animals $[3,20]$. Brachyspira hyodysenteriae quantification estimates in pens remaining positive revealed a log reduction of counts after cleaning $\left(1.40 \log _{10} \mathrm{CFU} / \mathrm{mL}\right)$, with no further improvement AD. A similar reduction in Enterobacteriaceae counts was achieved by a similar protocol including high-pressure washing in the lairage environment of a pig abattoir [16]. Disinfection and drying also removed Salmonella and reduced Enterobacteriaceae counts in the aforementioned study. We did not observe such benefit in B. hyodysenteriae estimates, with a reduction after disinfectant application on farm A positive pen $\left(1.79 \log _{10} \mathrm{CFU} / \mathrm{mL}\right)$ and had no effect on pens from farm $B$ either.

\section{Methods}

\section{Bacterial strains and disinfectants}

A set of ten isolates of $B$. hyodysenteriae kept in the bacteriological collection from the DIGESPORC research group at the University of León was used in this study. The isolates were recovered from the diagnosis submissions from diarrhoea outbreaks on Spanish swine farms between January 2018 and December 2019. Table 3 gives the list of isolates used and their antimicrobial profile, determined using a broth microdilution procedure as previously described [25] using VetMIC Brachy antibiotic panels (SVA, Sweden).

We collected information on disinfectants commonly used from nearby farms within our region, finally selecting eight commercial disinfectants and ethanol (used as effective disinfectant control). Details of disinfectants composition and use conditions are detailed in Table 4.

\section{In-vitro efficacy of disinfectant against $B$. hyodysenteriae}

The evaluation of bactericidal activity of disinfectants was carried out using a dilution-neutralisation method according to the recommendations of EN 1656:2009. In brief, $100 \mu \mathrm{L}$ of a bacterial suspension (approximately $10^{7} \mathrm{CFU} / \mathrm{mL}$ ) and $100 \mu \mathrm{L}$ of sterile faeces $\left(121^{\circ} \mathrm{C}, 15 \mathrm{~min}\right.$ in autoclave) as interfering substance were added to $800 \mu \mathrm{L}$ of each disinfectant diluted in hard water to obtain the concentration recommended by the manufacturers (Table 4). After $30 \mathrm{~min}$ incubation at $10^{\circ} \mathrm{C}, 100 \mu \mathrm{L}$ of the mixture was mixed with $100 \mu \mathrm{L}$ of sterile water and $800 \mu \mathrm{L}$ of Dey-Engley neutralising broth (BD Difco, United States) and again incubated for $5 \mathrm{~min}$ at $20^{\circ} \mathrm{C}$.

Estimation of the survival population was performed by plating ten-fold serial dilutions in phosphate-buffered saline (PBS, pH 7.4) into Trypticase Soy Agar (TSA)

Table 3 MIC values $(\mu \mathrm{g} / \mathrm{mL})$ of six antimicrobial agents obtained against the 10 B. hyodysenteriae isolates tested

\begin{tabular}{|c|c|c|c|c|c|c|c|c|c|c|}
\hline \multirow{3}{*}{$\begin{array}{l}\text { Antimicrobial agent and } \\
\text { concentration range }(\mu \mathrm{g} / \mathrm{mL})\end{array}$} & \multicolumn{10}{|c|}{$\mathrm{MIC}(\mu \mathrm{g} / \mathrm{mL})$} \\
\hline & \multicolumn{10}{|c|}{ Isolate } \\
\hline & IT-1 & IT-18 & IT-39 & IT-40 & IT-45 & IT-48 & IT-67 & IT-68 & IT-83 & IT-85 \\
\hline $\begin{array}{l}\text { Tiamulin } \\
(0.063-8)\end{array}$ & 8 & 0.125 & 1 & $>8$ & $>8$ & 4 & $>8$ & 1 & 0.125 & 0.5 \\
\hline $\begin{array}{l}\text { Valnemulin } \\
(0.031-4)\end{array}$ & $>4$ & $<0.031$ & 0.5 & 4 & 0.25 & 4 & $>4$ & 1 & $<0.031$ & 0.5 \\
\hline $\begin{array}{l}\text { Doxycycline } \\
(0.125-16)\end{array}$ & 1 & 1 & 0.25 & 2 & 16 & 1 & 16 & 2 & 1 & 0.5 \\
\hline $\begin{array}{l}\text { Tylvalosin } \\
(0.25-32)\end{array}$ & $>32$ & 4 & 0.5 & $>32$ & 1 & 2 & 16 & 8 & 8 & 1 \\
\hline $\begin{array}{l}\text { Lincomycin } \\
(0.5-64)\end{array}$ & 32 & 32 & 32 & $>64$ & $>64$ & $>64$ & 32 & 32 & 32 & 16 \\
\hline $\begin{array}{l}\text { Tylosin } \\
(2-128)\end{array}$ & $>128$ & $>128$ & 4 & $>128$ & $>128$ & $>128$ & 8 & $>128$ & $>128$ & $>128$ \\
\hline
\end{tabular}


Table 4 Composition and final concentration of the working solution of the disinfectants tested

\begin{tabular}{|c|c|c|}
\hline Disinfectant & Main bactericidal components and concentration & $\begin{array}{l}\text { Working } \\
\text { concentration }\end{array}$ \\
\hline $\begin{array}{l}\text { ET-70\% } \\
\text { (alcohol) }\end{array}$ & $70 \%$ ethanol & $100 \%^{\mathrm{a}}$ \\
\hline $\begin{array}{l}\text { Virkon-S } \\
\text { (peroxygen compound) }\end{array}$ & 49.7\% Pentapotassium bis(peroxymonosulphate) bis(sulphate) and organic acids & $1 \%$ \\
\hline $\begin{array}{l}\text { CR-36 } \\
\text { (alcohol and quaternary ammonium) }\end{array}$ & 0.256\% 2-bromo-2-nitro-1,3-propanediol & $100 \%^{\mathrm{a}}$ \\
\hline $\begin{array}{l}\text { Yodermin } \\
\text { (povidone-iodine) }\end{array}$ & 10\% Polyvinylpyrrolidone iodine (equal to 1\% available iodine) & $100 \%^{\mathrm{a}}$ \\
\hline $\begin{array}{l}\text { Poliformo } \\
\text { (Phenol) }\end{array}$ & $10 \%$ p-chloro-m-cresol & $2 \%$ \\
\hline $\begin{array}{l}\text { Limoseptic } \\
\text { (glutaraldehyde and quaternary ammonium) }\end{array}$ & 5\% glutaraldehyde and $4.5 \%$ didecyldimethylammonium chloride & $1 \%$ \\
\hline $\begin{array}{l}\text { MS Megades Novo } \\
\text { (glutaraldehyde and quaternary ammonium) }\end{array}$ & $15 \%$ glutaraldehyde and $10 \%$ quaternary ammonium & $0.75 \%$ \\
\hline $\begin{array}{l}\text { MS Megades Oxy } \\
\text { (peroxygen compound and peracetic acid) }\end{array}$ & 7.8\% hydrogen peroxide and $2.4 \%$ peracetic acid & $0.5 \%$ \\
\hline $\begin{array}{l}\text { Hypred Force } 7^{*} \\
\text { (glutaraldehyde and quaternary ammonium) }\end{array}$ & $\begin{array}{l}13 \% \text { glutaraldehyde, } 1.5 \% \text { didecyldimethylammonium chloride and } 8 \% \text { quaternary } \\
\text { ammonium compounds, benzylalkyldimethyl and chlorides }\end{array}$ & $2 \%$ \\
\hline
\end{tabular}

* HYPRED FORCE 7 was only tested under field conditions

a not diluted

supplemented with 5\% sheep blood (Oxoid, Spain). Finally, plates were incubated in a bug box anaerobic workstation (Baker Ruskinn, United States) with an oxygen-free anaerobic gas mixture $\left(80 \% \mathrm{~N}_{2}, 10 \% \mathrm{H}_{2}\right.$ and $10 \%$ $\mathrm{CO}_{2}$ ) at $39{ }^{\circ} \mathrm{C}$ for four-six days, the period after which the surviving population $\left(\log _{10} \mathrm{CFU} / \mathrm{mL}\right)$ was estimated. Each test was carried out in duplicate using a fresh culture suspension. B. hyodysenteriae reference strain B204 (ATCC 31212) and ethanol (ET-70\%) were also included as a quality control strain and disinfectant control, respectively.

Finally, the viability of $B$. hyodysenteriae in sterile faeces and neutralising broth was confirmed and the neutralising capacity of the Dey-Engley neutralising broth against each disinfectant was also checked before running the experiment.

\section{On-farm efficacy of cleaning and disinfection protocols}

Field efficacy of cleaning and disinfection protocols was evaluated on two commercial pig farms with endemic SD. A two-step protocol including power washing and disinfection with Hypred Force 7 was carried out on
Farm A while Farm B cleaning and disinfection protocol included pre-soaking with cold water and detergent, power washing with cold water and final disinfection with MS Megades Oxy. Farm characteristics, the specific soapy detergent and disinfectant used and number of pens per farm are detailed in Table 5 .

Following the same procedure, four squares of each pen evaluated (approximately $25 \mathrm{~cm}^{2}$ each) were swabbed BC and $\mathrm{AC}$ using a sterile gauze per pen placed into $50 \mathrm{~mL}$ of PBS ( $\mathrm{pH} 7.4$ ) and AD using a cellulose sponge per pen supplied in sterile bags with $10 \mathrm{~mL}$ of neutralising buffer (3 M HydraSponge, United States). In both AC and BD sampling, the pens were visually inspected before sampling and dirty areas were selected for swabbing if detected. Samples were handled aseptically under cooling conditions and processed within $24 \mathrm{~h}$ in the laboratory.

\section{Brachyspira hyodysenteriae detection and quantification by real-time PCR}

Gauzes and sponges embedded with PBS or neutralising buffer were placed into sterile bags and homogenized using a stomacher (Seward 400, UK) for 5 min. From

Table 5 Details of farms participating in the evaluation of the cleaning and disinfection against B. hyodysenteriae

\begin{tabular}{|c|c|c|c|c|c|c|}
\hline FARM & Type of swine production & $\begin{array}{l}\mathrm{N}^{\circ} \text { pens initially } \\
\text { included }\end{array}$ & Floor type & $\begin{array}{l}\text { Weight of } \\
\text { animals }\end{array}$ & Soapy detergent & Disinfectant \\
\hline A & Finishing unit & 8 & Part slatted (concrete) & $72 \mathrm{~kg}$ & Not used & Hypred Force 7 \\
\hline$B$ & Farrow to grower & 48 & Fully slatted (plastic) & $20 \mathrm{~kg}$ & MS TopFoam LC Alk & MS Megades Oxy \\
\hline
\end{tabular}


each sample, a final volume of $500 \mu \mathrm{L}$ were further used to extract DNA using GeneMATRIX Stool DNA Purification Kit (EurX, Poland), following the manufacturer's recommendations.

A species-specific real-time PCR assay was carried out to detect the presence of $B$. hyodysenteriae using the primers, probes and the cycling conditions previously described [26]. Each reaction mixture $(20 \mu \mathrm{L}$ final volume) contained $8 \mu \mathrm{L}$ of Maxima Probe real-time PCR Master Mix 2X (Thermo Scientific, Stockholm, Sverige), $0.3 \mu \mathrm{L}$ of $10 \mu \mathrm{M}$ each primer, $0.15 \mu \mathrm{L}$ of $10 \mu \mathrm{M}$ Taq-Man probe, $0.12 \mu \mathrm{L}$ of Rox (diluted 1:10 in nuclease-free water, Thermo Scientific, Sweden), 9.28 $\mu \mathrm{L}$ of nuclease-free water and $2 \mu \mathrm{L}$ of extracted DNA. The assay was carried out in a QuantStudio 1 thermal cycler (Applied Biosystems, United States) and the B. hyodysenteriae counts in targeted samples was estimated using a standard curve which was prepared using ten-fold serial dilutions of a B. hyodysenteriae B204 pure culture (initial load $8 \log _{10}$ $\mathrm{CFU} / \mathrm{mL}$ and range 8 to $2 \log _{10} \mathrm{CFU} / \mathrm{mL}$ ). DNA extraction of standard curve broth was carried out as described above for environmental samples. The detection limit was defined by the linear portion of the standard curve and was set at $3 \log _{10} \mathrm{CFU} / \mathrm{mL}$ (Cycle threshold value of 35.7). Each DNA sample was analysed in duplicate.

\section{Brachyspira hyodysenteriae detection and isolation in selective media}

In parallel to real-time PCR detection and quantification of $B$. hyodysenteriae, samples were cultured to detect, isolate and purify $B$. hyodysenteriae following the methodology described [27]. In brief, TSA plates (Scharlab, Spain) supplemented with $5 \%$ ovine blood (Oxoid, Spain) and antibiotics $(400 \mu \mathrm{g} / \mathrm{mL}$ spectinomycin, $8 \mu \mathrm{g} / \mathrm{mL}$ colistin and $20 \mu \mathrm{g} / \mathrm{mL}$ vancomycin, Sigma-Aldrich, United States) was used for primary isolation. Suspected positive samples showing strong $\beta$-haemolysis and spirochaetes in phase-contrast microscopy were confirmed using species-specific PCR based on the tlyA gene [28]. TSA supplemented with $5 \%$ ovine blood agar (Oxoid, Spain) was further used for subsequent subcultures until a pure growth was confirmed by phase-contrast microscopy. All cultures were carried out under optimal conditions for the growth of $B$. hyodysenteriae previously described.

\section{Statistical analysis}

The analysis was carried out with IBM SPSS Statistics version 26 at the $5 \%$ significance level. The B. hyodysenteriae counts $\left(\log _{10} \mathrm{CFU} / \mathrm{mL}\right)$ estimated by real-time PCR were tested for normality (Kolmogorov-Smirnov test) and statistical differences among different samplings ( $B C, A C$ and $A D)$ were evaluated using the ANOVA test. Differences in proportions of positive pens among farm $A$ and farm $B$ were checked using chi-square or Fisher's exact tests where appropriate.

\section{Conclusions}

This study shows the susceptibility of B. hyodysenteriae field isolates to currently used commercial disinfectants under laboratory conditions. However, in practice, the cleaning and disinfection protocols evaluated in this study frequently failed to remove $B$. hyodysenteriae, probably, as a consequence of deficient pen faecal removal. Using real-time PCR, we showed a high load of the pathogen in emptied pens and a low reduction achieved using protocols tested. The result is a warning for farms with endemic SD that the cleaning and disinfection protocols in use should be evaluated.

\section{Abbreviations}

SD: Swine dysentery; AI/AO: All-in/all-out; EN: European Norm; CFU: Colony forming units; BC: Before cleaning; AC: After cleaning and before disinfection; AD: After disinfection; PBS: Phosphate-buffered saline; TSA: Trypticase Soy Agar; ATCC: American Type Culture Collection.

\section{Acknowledgements}

We acknowledge the excellent technique assistance provided by Diana Molina, as well as the help and willingness of veterinary practitioners and farmers.

\section{Authors' contributions}

Study design and direction: MGG, HA, PR and AC. In-vitro experiments: MGG, LPP, CV, HP and OM. Analysis of the results and writing of the manuscript: MGG, HA and AC. All authors read and approved the final manuscript.

\section{Authors' information}

Manuel Gómez (LE131-18) and Clara Vega (workplace ULE-02-B) were supported by grants from Junta de Castilla y León co-financed by the European Social Fund and Youth Employment Initiative. Héctor Argüello is supported by the Spanish Ministry of Education under the programme "Beatriz Galindo" (BEAGAL-18-106). Lucía Pérez-Pérez (PRE2020-093762), Óscar Mencía-Ares (FPU16/03485), Héctor Puente (FPU17/00466) are also supported by the Spanish Ministry of Education.

\section{Funding}

This study was supported by the Ministerio de Ciencia e Innovación (PID2019-1 10662RB-100) and the Castilla y León Rural Development Programme co-financed by EAFRD (47/18/125/G02).

Availability of data and materials

The authors declare that they did not apply new software and databases.

\section{Declarations}

Ethics approval and consent to participate Not applicable.

\section{Consent for publication}

Not applicable.

\section{Competing interests}

The authors declare that they have no competing interests. 
Received: 11 October 2021 Accepted: 16 December 2021

Published online: 08 January 2022

\section{References}

1. Burrough ER. Swine Dysentery: Etiopathogenesis and Diagnosis of a Reemerging Disease. Vet Pathol. 2017. https://doi.org/10.1177/03009 85816653795

2. Neirynck W, Boyen F, Chantziaras I, Vandersmissen T, Vyt P, Haesebrouck $F$, et al. Implementation and evaluation of different eradication strategies for Brachyspira hyodysenteriae. Porc Heal Manag. 2020. https://doi.org/10. 1186/s40813-020-00162-2.

3. Alvarez-Ordóñez A, Martínez-Lobo FJ, Arguello H, Carvajal A, Rubio P. Swine dysentery: Aetiology, pathogenicity, determinants of transmission and the fight against the disease. Int J Environ. 2013. https://doi.org/10. 3390/ijerph10051927.

4. Paster BJ, Dewhirst FE. Phylogenetic foundation of spirochetes. J Mol Microbiol Biotechnol. 2000. p. 341-4.

5. Mirajkar NS, Phillips ND, La T, Hampson DJ, Gebhart CJ. Characterization and recognition of Brachyspira hampsonii sp. Nov., a novel intestinal spirochete that is pathogenic to pigs. J Clin Microbiol. 2016. https://doi. org/10.1128/JCM.01717-16.

6. Rubin J, Costa M, Hill J, Kittrell H, Fernando C, Huang Y, et al. Reproduction of mucohaemorrhagic diarrhea and colitis indistinguishable from swine dysentery following experimental inoculation with 'Brachyspira hampsonii' strain 30446. PLoS ONE. 2013. https://doi.org/10.1371/JOURNAL.PONE. 0057146.

7. Desrosiers R. Transmission of swine pathogens: different means, different needs. Anim Health Res Rev. 2011. https://doi.org/10.1017/S146625231 0000204.

8. Rugna G, Bonilauri P, Carra E, Bergamini F, Luppi A, Gherpelli Y, et al. Sequence types and pleuromutilin susceptibility of Brachyspira hyodysenteriae isolates from Italian pigs with swine dysentery: 2003-2012. Vet J. 2015. https://doi.org/10.1016/j.tvjl.2014.10.033.

9. Carvajal A, de Arriba ML, Rodríguez H, Vidal AB, Duhamel GE, Rubio P, et al. Prevalence of Brachyspira species in pigs with diarrhoea in Spain. Vet Rec. 2006. https://doi.org/10.1136/vr.158.20.700.

10. Hidalgo Á, Carvajal A, Vester B, Pringle M, Naharro G, Rubio P. Trends towards lower antimicrobial susceptibility and characterization of acquired resistance among clinical isolates of Brachyspira hyodysenteriae in Spain. Antimicrob Agents Chemother. 2011. https://doi.org/10.1128/ AAC.01749-10.

11. Bragg RR, Meyburgh CM, Lee JY, Coetzee M. Potential treatment options in a post-antibiotic era. Adv Exp Med Biol. 2018. https://doi.org/10.1007/ 978-981-10-7572-8_5.

12. Jayaraman B, Nyachoti CM. Husbandry practices and gut health outcomes in weaned piglets: A review. Anim Nutr. 2017. https://doi.org/10. 1016/j.aninu.2017.06.002.

13. Frentzel H, Menrath A, Tomuzia K, Braeunig J, Appel B. Decontamination of High-risk Animal and Zoonotic Pathogens. Biosecurity Bioterrorism Biodefense Strateg Pract Sci. 2013. https://doi.org/10.1089/bsp.2012. 0069.

14. Bragg R, Jansen A, Coetzee M, van der Westhuizen W, Boucher C. Bacterial resistance to quaternary ammonium compounds (QAC) disinfectants. Adv Exp Med Biol. 2014. https://doi.org/10.1007/978-81-322-1774-9_1.

15. Mc Carlie S, Boucher CE, Bragg RR. Molecular basis of bacterial disinfectant resistance. Drug Resist Updat. 2020. https://doi.org/10.1016/j.drup. 2019.100672.

16. Walia K, Argüello H, Lynch H, Grant J, Leonard FC, Lawlor PG, et al. The efficacy of different cleaning and disinfection procedures to reduce Salmonella and Enterobacteriaceae in the lairage environment of a pig abattoir. Int J Food Microbiol. 2017. https://doi.org/10.1016/j.ijfoodmicro. 2017.02.002.

17. Cadetg RSS, Vidondo B, Nathues H, Schüpbach G, Zeeh F. Retrospective study on the eradication of Swine Dysentery (Brachyspira hyodysenteriae) in Switzerland. Schweiz Arch Tierheilkd. 2019. https://doi.org/10.17236/ sat00202.

18. Giacomini E, Gasparrini S, Lazzaro M, Scali F, Boniotti MB, Corradi $A$, et al. The role of transportation in the spread of Brachyspira hyodysenteriae in fattening farms. BMC Vet Res. 2018. https://doi.org/10. 1186/s12917-017-1328-5.

19. Alarcón LV, Allepuz A, Mateu E. Biosecurity in pig farms: a review. Porc Heal Manag. 2021. https://doi.org/10.1186/S40813-020-00181-Z.

20. Lobova D, Cizek A. Bactericidal efficacy of two disinfectants against Brachyspira hyodysenteriae and one feed supplement against $B$. hyodysenteriae and B. pilosicoli. Vet Med (Praha). 2004. https://doi.org/10.17221/ 5690-VETMED.

21. Corona-Barrera E, Smith DGE, Murray B, Thomson JR. Efficacy of seven disinfectant sanitisers on field isolates of Brachyspira pilosicoli. Vet Rec. 2004. https://doi.org/10.1136/vr.154.15.473.

22. Martínez-Martínezi S, Ryubero-Delgado S, Rodríguez-Ferri EF, Frandoloso R, Álvarez-Estrada Á, Gutiérrez-Martín CB. In vitro efficacy of several disinfectants against Salmonella enterica serovar Enteritidis and Escherichia coli strains from poultry. Cienc Rural. 2016. https://doi.org/10.1590/0103$8478 \mathrm{cr} 20151288$

23. Wales A, Breslin M, Davies R. Assessment of cleaning and disinfection in Salmonella-contaminated poultry layer houses using qualitative and semi-quantitative culture techniques. Vet Microbiol. 2006. https://doi.org/ 10.1016/j.vetmic.2006.04.026

24. Jacobson M, Fellström C, Lindberg R, Wallgren P, Jensen-Waern M. Experimental swine dysentery: comparison between infection models. J Med Microbiol. 2004. https://doi.org/10.1099/JMM.0.05323-0.

25. Karlsson M, Fellström C, Gunnarsson A, Landén A, Franklin A. Antimicrobial susceptibility testing of porcine Brachyspira (Serpulina) species isolates. J Clin Microbiol. 2003. https://doi.org/10.1128/jcm.41.6.25962604.2003.

26. Song Y, Hampson DJ. Development of a multiplex qPCR for detection and quantitation of pathogenic intestinal spirochaetes in the faeces of pigs and chickens. Vet Microbiol. 2009. https://doi.org/10.1016/j.vetmic.2008 12.020.

27. Hidalgo Á, Carvajal A, García-Feliz C, Osorio J, Rubio P. Antimicrobial susceptibility testing of Spanish field isolates of Brachyspira hyodysenteriae. Res Vet Sci. 2009. https://doi.org/10.1016/j.rvsc.2008.10.017.

28. Råsbäck T, Fellström C, Gunnarsson A, Aspán A. Comparison of culture and biochemical tests with PCR for detection of Brachyspira hyodysenteriae and Brachyspira pilosicoli. J Microbiol Methods. 2006. https://doi.org/ 10.1016/j.mimet.2005.12.008.

\section{Publisher's Note}

Springer Nature remains neutral with regard to jurisdictional claims in published maps and institutional affiliations.

Ready to submit your research? Choose BMC and benefit from

- fast, convenient online submission

- thorough peer review by experienced researchers in your field

- rapid publication on acceptance

- support for research data, including large and complex data types

- gold Open Access which fosters wider collaboration and increased citations

- maximum visibility for your research: over 100M website views per year

At BMC, research is always in progress.

Learn more biomedcentral.com/submissions 